\title{
Ethics Challenges and Business Investment: The Case of the Ponzi Schemes in the USA
}

\author{
Paul Matshona \\ PhD candidate, Zimbabwe Open University
}

\begin{abstract}
This desktop paper demonstrates how some business people dupe clients for selfish gains. The paper discusses the 'Ponzi schemes' under Madoff. Madoff had a well thought out process to deceive people in believing that he was a genuine investment advisor. Yet he simply wanted to benefit himself at the expense of investors. He lacked moral capacity, making him continue to lie and trick investors for over 30 years. The discussion in this paper shows that there is need to train entrepreneurs and business leaders in ethical issues. Madoff lacked values to guide him to act right.
\end{abstract}

Key words: Ethics, investment, business, entrepreneurs, leaders

DOI: $10.7176 /$ PPAR/9-3-09

Publication date:March $31^{\text {st }} 2019$

\section{Introduction}

Business ethics is a neglected area in most cases. Too often consumers and unsuspecting investors are left at the mercy of greedy and unscrupulous 'business people'. This paper discusses the case of the Ponzi schemes under the leadership of Madoff. The paper starts by discussing the Madoff before drawing some conclusions and giving recommendations.

\section{The Ponzi case}

According to Kostigen (2009), Bernard Madoff allegedly ran a \$50 billion Ponzi scheme, that "when discovered, ruined many a life savings." It is clear, as stated by Kostigen (2009), "that Madoff was the mastermind." However, it is not clear, who among his employees knew about the scam. Ponzi schemes are named after Charles Ponzi "who cheated more than 40,000 Bostonians in the early 1900 s by promising a $50 \%$ return in 45 days" (Benson, 2009, p.20).

Benson (2009) states that "the largest reported Ponzi scheme in history is the scheme run by Bernard L. Madoff, a former chairman of Nasdaq" (p.20). According to Benson (2009), "Madoff was arrested on December 11, 2008, for operating a $\$ 65$ billion Ponzi scheme that may have lasted over three decades" (p.20). On March 12, 2009, Bernard Madoff pleaded guilty to 11 felony counts, including securities fraud (Benson, 2009, p.20). Madoff and his team's work "revolved around the pretense that securities were being bought and sold" (Lewis, 2013, p.365). Madoff's victims not only suffered the loss of their investments, but also lost money paid to the IRS for the gains on their investments. Kramer \& Ward (2009) states that "Ponzi scheme losses present difficult tax issues. And taxes already paid on fictitious gains (phantom income) are not easily recovered" (p.27). For Madoff's victims "this investment scam extends beyond the financial loss and includes undesired media coverage and perhaps public humiliation” (Glodstein, Glodstein \& Fornaro, 2010, p.2).

Madoff showed poor moral judgement. Moral judgement is "defined as the determination of ethical appropriate course of action among potential alternatives," (Schwartz, 2016, p. 757). Madoff used intuition, resulting in him making bad moral judgement. Since he made a choice, then an ethical issue exists (p. 759). According to Schwartz (2016), the rationalist models emphasize "the rational cognitive process used by decision-makers to resolve ethical dilemmas." (p. 759). Non-rationalist models involve intuition and emotions or sentiments. An effective process should be considered more central or 'sovereign' to the moral judgement process of ethical decision-making. Madoff could apply non-rationalist's view to justify his actions. Madoff showed no emotions or sentiments. He also showed a lack of "pro-social" emotions, which according to Schwartz (2016), "promote morally good behavior such as empathy, sympathy, concern or compassion" (p. 760).

Schwartz (2016) states that "people have a built-in moral sense that creates pleasurable feelings of approval towards benevolent acts and corresponding feeling of disapproval towards evil and vice (p. 760). To his credit, Madoff seems to have a well thought out process to deceive people in believing that he was a genuine investment advisor, but all he did was benefit himself and his accomplices. If we consider the individual factor, Madoff was feeding his own ego, and lacked good values. He lacked moral capacity, making him continue to lie and trick more investors for over 30 years. Moral capacity, according to Schwartz (2016), is defined as "the ability of an individual to avoid moral temptations, engage in the prosper resolution of ethical dilemmas and ultimately engage in ethical behavior" (p.761).

His moral character disposition was flawed since he exhibited no ethical ideology nor moral maturation. Madoff's "metacognitive ability showed no match or growth to enable him to act in an ethical way when dealing 
with his clients' investments. Integrity capacity is defined as "capability for repeated process alignment of moral awareness, deliberations, character and conduct" (Schwartz, 2016, p.722). He lacked integrity capacity, even though he protected his accomplices resulting in him alone being indicted. Religion can help shape one's moral behavior because of believing in the divine will of God, Madoff exhibited no sense of respect for divine will of God. It was all about himself alone. Madoff Investments lacked the ethical infrastructure that could have possibly promoted ethical decisions. Ethical infrastructure is defined as "the organizational elements that contribute to an organization's ethical effectiveness" (Schwartz, 2016, p.764). Madoff lacked moral awareness since he was deceiving investors from day one and further lied by providing statements that were fraudulent and misleading the investors. He suffered from ethical fading making him unable to perceive the implications of his actions. He, according to Schwartz (2016), suffered from moral blindness. Moral blindness is defined as "the decision maker's temporary inability to see the ethical dimension of a decision at stake" (Schwartz, 2016, p. 766). Madoff also suffered from moral myopia, which is defined as "a distortion of moral vision that prevents moral issues from coming into focus" (Schwartz, 2016, p.766). Madoff was driven by greed and seems not to believe in the common good or just doing what is right. Madoff did not think about consequences of his actions because if he did, he should have stopped at one point. Forecasting the impact of potential consequences was found to be positively related to more effective ethical decisions" (Bagdasarov et. al., 2016, p.134). It is probable that Madoff could have made ethical decisions of higher caliber if he thought through the consequences, for example, loss of his freedom or how it would inconvenience his family. Madoff probably lacked training in ethics that could have helped to improve his ethical decision making. Training has proved to positively impact mental model and resulted in "solutions of higher quality and originality" (Bagdasarov et.al., 2016, p.135).

Madoff was driven by greed and felt that he could get away with his actions unpunished. After being the chairman of the Nasdaq, that gave him the authenticity he needed to defraud more investors. He realized he won public confidence and took advantage of the investors by operating the Ponzi scheme for personal gain. He wanted a lavish life as shown by the things he bought for himself and his family. His heartlessness is shown by his lack of empathy for people who brought to him their life savings intending to increase them, yet he used those savings to satisfy his greed. He acted selfishly and unethically. He showed lack of good morals, just to believe that one should do good just because it is the right thing to do. Madoff acted in a way that shows he was only concerned with his own personal pleasure and not of the investors whom he had a duty to protect their investments. Giving him $\$ 65$ billion shows the investors had put their trust in him. Besides the legal implications of Madoff's actions, what he did was morally wrong. Madoff was supposed to be honest with his investors just because that is the right thing to do. He had a duty to act in an honest way. Madoff's actions might have been influenced by the lack of religious beliefs. Religious deontologists believe that the "source of duty is divine will, and what one ought to do in the particular situation is what God wills for one to do in that situation, as given directly or through as inspired mediator" (Hull, 1979, p).

\section{Conclusions}

The above discussion shows that there is need to train future leaders in ethical issues to save investors from being swindled of their money by criminals and fraudulent people. Even with the laws that are meant to protect investors there are people who, due to greedy, choose to use illegal and unethical means to gain wealth. When investors develop trust for the fraudster, it becomes very easy for them to believe the person and loose the ability to question the promises made by the fraudster. Madoff took advantage of that trust to defraud many people and made them recruit more victims.

Madoff lacked values to guide him to act right. It is clear, that Madoff lacked the moral capacity to act in a good way as expected by society. These factors, according to Schwartz (2016), also affect the ego strength (p.762). He overlooked all the other factors and went ahead with his plan to cheat investors to satisfy his greed. Neither did he evaluate his actions nor recognize that his actions were wrong. He continued to satisfy his ego and continued to swindle investors of their hard earned money.

\section{Future Research}

Future research should focus on what makes a person lose his or her moral capacity. Such a research will help to ensure people who have such traits or background should not be put in positions of authority where they can abuse their power for personal gain.

\section{References}

Bagdasarov, Z., Johnson, J., MacDougall, A., Steele, L., Connelly, S., \& Mumford, M. (2016). Mental models and ethical decision making: The mediating role of sensemaking. Journal of Business Ethics, 138(1), 133144. Retrieved from http://proxyl.ncu.edu/login?url=http://search.ebscohost.com/login.aspx?direct=true\&d bth\&AN $=118005408 \&$ site $=$ eds-live

Benson, S. S. (2009). Recognizing the Red Flags of a Ponzi Scheme. (cover story). CPA Journal, 79(6), 18-25. 
Glodstein, D., Glodstein, S. L., \& Fornaro, J. (2010). Fraud Trauma Syndrome: The Victims of the Bernard Madoff Scandal. Journal of Forensic Studies in Accounting \& Business, 2(1), 1-9.

Hull, R. T (1979). The Varieties of Ethical Theories, "Buffalo Psychiatric Center," (March 27, 1979).

Kostigen, T (2009). The 10 Most Unethical People in Business.

Kramer, A. S., \& Ward, T. P. (2009). Bernie Madoff "Made Off" with My Investment: Evaluating the Tax Options Available for Victims of Fraudulent Investments. Journal of Taxation of Financial Products, 8(2), 27-60.

Kranacher, M. (2009, April). Accounting for the Madoff Fraud. CPA Journal. p. 80.

Lewis, L. (2013). The Confidence Game: Backstage, the Accomplices. doi:10.1007/s12115-013-9675-8

Schwartz, M. (2016). Ethical decision-making theory: An integrated approach. Journal of Business Ethics, 139(4), 755-776. Retrieved

http://proxy1.ncu.edu/login?url=http://search.ebscohost.com/login.aspx?direct=true\&d

bth\&AN $=119754908 \&$ site $=$ eds-live 